\title{
Vasilij Abajev 1900-2001
}

\author{
Silvo Torkar
}

Le nekaj mesecev potem, ko so najuglednejši moskovski jezikoslovci pripravili veliko svečanost ob stoletnici rojstva Vasilija Abajeva, enega najpomembnejših primerjalnih indoevropskih jezikoslovcev 20. stoletja, patriarha ruske iranistike, enciklopedista osetinskega jezika in folklore, se je (18. marca) njegovo življenje utrnilo. Zaradi izjemne osebne skromnosti in nevključevanja v vsakršne klane so o V. Abajevu v medijih, celo v strokovnih, razmeroma malo pisali. Šele ob stoletnici je Ruska akademija znanosti (RAN) izdala knjigo o življenju in delu velikega učenjaka izpod peresa njegovega učenca in rojaka Mahometa Isajeva, opremljeno s predgovorom akademika Olega Trubačova in z bibliografijo del slavljenca. ${ }^{1}$ V resnici gre za ponatis širši javnosti praktično nedostopnega besedila iz leta 1980, ki je izšlo v skromni knjižici pri založbi Ir $^{2}$ v Ordžonikidzeju (od leta 1990 spet Vladikavkazu), glavnem mestu Severne Osetije - Alanije.

Polmilijonski osetinski narod, potomec nekdaj mogočnih ljudstev Skitov, Sarmatov in Alanov, je znan po dveh osebnostih, ki sta ključni za poznavanje in razumevanje njegove jezikovne in kulturne identitete. Prvi je Kosta Hetagurov, pesnik, utemeljitelj sodobne osetinske literature in vsestranski nacionalni buditelj (1859-1906), drugi je Vasilij Abajev, jezikoslovec in folklorist, avtor impresivnega Istoriko-etimologičeskogo slovarja osetinskogo jazyka $\mathrm{v}$ petih debelih $\mathrm{knjigah}^{3}$ in številnih znanstvenih monografij.

Vasilij ali tudi Vaso Abajev se je rodil 15. decembra 1900 v visokogorski vasi Kobi ob Vojaški gruzinski cesti. Po končani klasični gimnaziji v Tiflisu (Tbilisiju) leta 1918 je nekaj let poučeval v rojstni vasi, nato pa je študiral iranistiko na univerzi v Leningradu. Na predlog znamenitega jezikoslovca Nikolaja Marra je tam leta 1928 opravil tudi podiplomski študij. Znanstvene naslove je pridobil brez zagovorov, na podlagi izjemnih dosežkov (leta 1935 in 1962). Pred vojno je delal v Leningradu, med vojno pa po srečnem naključju v Severni in Južni Osetiji. Po zna-

1 Isaev, M.I., Vasilij Ivanovič Abaev, Moskva, »Nauka«, 2000.

2 Ir je osetinsko etnično samopoimenovanje. Ime Osetija (dobesedno Oseti) je gruzinsko in je prešlo v vse evropske jezike. Izpeljano je iz etnonima $O s$ in pomeni deželo, kjer $O s i$ živijo (prim. še Rusi-Ruseti). Osetin je rusko poimenovanje za pripadnika obravnavanega naroda, v slovenščini ime ni docela ustaljeno: Osetinec, osetinski, osetinščina, v rabi je tudi Oset, osetski, osetščina (prim. nam najbližjo podobno podaljšavo Dalmatinec, dalmatinski iz podstave Dalmatia.

3 Abaev, V.I., Istoriko-etimologičeskij slovar' osetinskogo jazyka, T. I (1958), T. II (1970), T. III (1979), T. IV (1989), T. V- Kazalo (1995), Moskva - Leningrad. 
nem Stalinovem članku v Voprosih jazykoznanija leta 1950, s katerim je bil končno presekan marristični vozel, so ga najvišje avtoritete $\mathrm{v}$ tedanji akademski srenji na čelu z V.V. Vinogradovom obtožile marrizma in čeprav je prepričljivo zavrnil vse očitke, je že kazalo, da ga bodo zaprli. Kljub temu da ni bil član partije in je zavestno izbral življenje »apolitičnega« znanstvenika, ga je tedaj sam Stalin, ki je včasih pokazal spoštovanje do pogumnih osebnosti, premestil iz Leningrada v Moskvo za namestnika V. V. Vinogradova, direktorja akademijskega Inštituta za jezikoslovje. Tu je v sekciji za iranske jezike delal do upokojitve 1. 1970.

Seznam znanstvenih del V. Abajeva obsega nad 300 enot, od tega trideset monografij. Področja njegovega dela so bila: jezikoslovje (iranistika, teorija jezika, izvor jezika v zgodnjih stadijih, teorija etimoloških in zgodovinskojezikoslovnih raziskav, indoevropsko in kavkaško jezikoslovje), vprašanja folkloristike, literarne vede, mitologije, religije, kulturne zgodovine in etnologije iranskih narodov.

Njegova prva znanstvena objava je razprava Ob udarenii v osetinskom jazy$k e$ (1924). Poleg številnih dialektoloških razprav sta, kar zadeva raziskave na sinhroni ravni, zelo pomembna njegova Russko-osetinskij slovar' in Osetinsko-russkij slovar' (1950 in 1952) ter Grammatičeskij očerk osetinskogo jazyka (1952). Poglavitno mesto v raziskovalnem delu V. Abajeva pa zavzemajo njegove raziskave na diahroni ravni, saj je jezik dojemal kot zgodovinski pojav, ki je najtesneje povezan z zgodovino naroda, njegove kulture, filozofskih in verskih nazorov ter vsakdanjega življenja. Program svojih raziskav je najbolj natančno sformuliral v razpravi Proishoždenie i kul'turnoe prošloe osetin po dannym jazyka (lingvističeskoe vvedenie $v$ istoriju osetinskogo naroda), ki uvaja njegovo prvo veliko, celih 600 strani obsegajočo knjigo Osetinskij jazyk i fol'klor. ${ }^{4}$

Večji del svojega življenja je posvetil uresničevanju tega monumentalnega raziskovalnega programa. V. Abajev je dal izjemen prispevek k raziskovanju vprašanja o starodavnih prednikih osetinskega jezika, namreč o bolj oddaljeni skitščini in nekoliko bližji alanščini. Ugotovil in preiskal je kavkaške substratne prvine $\mathrm{v}$ osetinščini. V delu Skifo-evropejskie izoglossy ${ }^{5}$ je V. Abajev prikazal v osetinščini poteze, ki jo zbližujejo s slovanskimi, baltskimi in germanskimi jeziki. Kot jezikoslovec se je posvečal raziskavam vseh ravnin jezika, najbolj pa ga je pritegnila leksika. Največji dosežek njegovega znanstvenega opusa je pač petzvezkovni Zgodovinsko-etimološki slovar osetinskega jezika, ki ga je sam pisal celih sedemdeset let in za katerega je izjemoma še pred izidom zadnje knjige prejel leta 1981 najvišje priznanje, Državno nagrado. V slovar je avtor pritegnil gradivo iz 190 jezikov in narečij. Poleg treh temeljnih načel, namreč fonetičnega, morfološkega in semantičnega, je V. Abajev pri pisanju tega dela kot četrti kriterij v veliki meri upošteval tudi

4 Abaev, V. I., Osetinskij jazyk i fol'klor, Leningrad 1949.

5 Abaev, V. I., Skifo-evropejskie izoglossy. Na styke Vostoka i Zapada, Moskva 1965. Zelo podroben kritičen pretres te razprave podaja V. Cvetko Orešnik v svoji knjigi K metodologiji preučevanja baltoslovansko-indoiranskih jezikovnih odnosov, Ljubljana 1998, na str. 66-81. V svoji študiji avtorica razčlenjuje še štiri krajše razprave V. Abajeva. 
»zgodovinski kontekst« oz. realije. Etimolog mora biti po Abajevu bolj kot vsak drug jezikoslovec oborožen s poznavanjem zgodovine, kulture, etnografije, folklore, arheologije ipd. Slovar je zato zanimiv tudi za zgodovinarje in etnologe. V njem najdemo prvine petih različnih tipov slovarjev: 1. dvojezičnega (je osetinsko-ruski), 2. razlagalnega (dokumentiran je z iztržki iz folklornih in literarnih besedil), 3 . etimološkega (iranski prototip, indoevropski prototip, novo- in srednjeiranski jeziki, avestijski, staroperzijski, staroindijski, slovanski, baltski, germanski, toharski, italski, keltski, grški, armenski, hetitski jezik), 4. zgodovinskega, 5. slovarja pojmov s področij materialne kulture, etnografije, folklore, religije.

Akademik Oleg Trubačov je o etimološkem opusu Abajeva rekel, da njegova etnolingvistična rekonstrukcija zgodovine malega naroda vodi v takšne daljave in prejema takšne razsežnosti, da lahko pred njimi ostrmiš.

Pomen Slovarja je toliko večji, če vemo, da gre v primeru osetinščine za t.i. mladi književni jezik, saj so prve zapise osetinskih besed napravili učeni tuji popotniki šele konec 17. stol. (če seveda ne štejemo alanskega napisa - z grškimi črkami - na nagrobnem kamnu iz X.-XII. stol., najdenem leta 1888 ob reki Zelenčuk, ali pa seznama besed v jeziku madžarskih Alanov, t.i. Jasov ${ }^{6}$, v listini iz leta 1422), prve knjige pa so s konca 18. stol. Prvi poglobljeni raziskovalec osetinskega jezika je bil šele A. Šegren, avtor znanstvene Osetinske slovnice s priloženim osetinsko-ruskim in rusko-osetinskim slovarjem. ${ }^{7}$ Pravi utemeljitelj vede o osetinskem jeziku in kulturi pa je bil Vsevolod F. Miller, slavist, iranist in kavkazolog, znan po svojih »Osetinskih etjudah ${ }^{8}$ in še zlasti po Osetinsko-rusko-nemškem slovarju, ki pa je izšel šele posmrtno. ${ }^{9}$

V. Abajev je bil tudi odličen raziskovalec severnokavkaškega ljudskega epa o junakih Nartih, ki se je pri Osetincih ohranil v večji meri kot pri sosednjih narodih. O njem pravi, da predstavlja poetizirano in fantastično avtobiografijo alanskega ljudstva, v kateri se je odsvitala zgodovina njegovega vsakdanjega življenja in pogleda na svet. Veliki francoski raziskovalec indoevropske mitologije in kavkazolog George Dumézil v svojem delu Mit in ep (1968) med drugim poudarja, da pomembnost Osetincev, tega malega severnokavkaškega ljudstva, za vse oblike primerjalnih študij samo narašča.

Ko so delovni in življenjski opus V. Abajeva ocenjevali njegovi mlajši kolegi, je bilo o njem med drugim rečeno: ${ }^{10} »$ Znanstvenike navadno delimo na dva tipa: eni razpletajo zapleteno, drugi po svojih močeh zapletajo preproste stvari. O Abajevu lahko mirno trdimo, da je občutno prispeval k razpletanju klobčiča izjemno zapletenih temeljnih problemov humanističnih znanosti«.

6 Kaloev, B. A., Vengerskie alany (jasy). Istoriko-etnografičeskij očerk, Moskva 1996.

7 Šegren, A., Osetinskaja grammatika, Sankt-Peterburg 1844.

8 Miller, Vs., Osetinskie etjudy, I-III, Moskva 1881-1887.

9 Miller, Vs., Osetinsko-russko-nemeckij slovar'. Pod redakciej is dopolnenijami A.A.Frejmana, I-III, Moskva 1927-1934.

${ }^{10}$ Efimov, V. A., Vasilij Ivanovič Abaev (1900-2001), Voprosy jazykoznanija, 2001, št. 4, 157. 